\title{
Entrevista com Sônia Rubinsky
}

André Repizo Marques

Universidade Estadual Paulista andre_repizo@hotmail.com

Resumo: Entrevista com a pianista brasileira Sônia Rubinsky. A presente entrevista contribuiu imensamente para a pesquisa acadêmica de mestrado (concluída em 26 de junho de 2017) do entrevistador, que tem por propósito investigar a diversidade de interpretações da obra de Ernesto Nazareth, cuja performance tem sido realizada tanto por pianistas eruditos como por rodas de choro.

Palavras-chave: Ernesto Nazareth. Choro. Interpretação.

\section{Interview with Sônia Rubinsky}

Abstract: Interview with Brazilian pianist Sônia Rubinsky. The present interview contributed immensely to the interviewer's academic master's research (concluded on June 26, 2017), which aims to investigate the diversity of Ernesto Nazareth interpretations, whose music has been performed by classical pianists and choro groups.

Keywords: Ernesto Nazareth. Choro. Interpretation.

\section{Apresentação}

Às 10 horas do dia vinte e um de novembro de 2016, tive o privilégio de entrevistar a pianista brasileira Sônia Rubinsky on-line, via Skype.

Com uma carreira internacional sólida e atuante no meio erudito, a pianista tem em sua trajetória o Conservatório Musical de Campinas, a Academia RUBIN de Jerusalém (cujo nome atual é "The Jerusalem Academy of Music and Dance"), e seu doutorado na Juilliard School em Nova York. Sônia Rubinsky é conhecida pelo registro integral da obra de Villa-Lobos em 8 volumes, fruto de 12 anos de pesquisa em manuscritos e com a cooperação do Museu Villa-Lobos no Rio de Janeiro. A pianista também conta em sua discografia obras de Bach, Debussy, Messiaen, Scarlatti, Mozart, Mendelssohn (integral das Canções Sem Palavras), Jorge Liderman, Gabriela Lena Frank e Ernesto Nazareth. ${ }^{1}$

O primeiro contato, via e-mail, com Sônia Rubinsky foi para apresentar minha pesquisa e convidá-la para uma entrevista acerca da interpretação ao piano, sobretudo a obra de Ernesto Nazareth. A pianista gravou quatro músicas do referido compositor para

\footnotetext{
${ }^{1}$ Disponível em: $<$ http://soniarubinsky.com/br/bio $>$. Acesso em 24/02/2017.
} 
o CD A revelação do homem célebre (2007). As músicas sob sua interpretação são: “Cruz perigo!" (1879); "Rayon d'or" (1892); "Batuque” (1913) e "Floraux" (1909). Este CD faz parte do livro $O$ enigma do homem célebre: ambição e vocação de Ernesto Nazareth (MACHADO, 2007).

Após alguns e-mails, marcamos a entrevista. Segue a transcrição.

André Repizo Marques: Fale-me um pouco sobre a sua formação como pianista.

Sônia Rubinsky: Minha formação como pianista foi muito eclética. Uma vez eu fiz uma entrevista, que agora não lembro com quem foi, no rádio, e ele queria que eu desse as minhas origens em termos de escolas pianísticas. Eu comecei a colocar no papel e eu não tinha noção disso. Só quando eu tive de responder essa questão, eu me dei conta que, praticamente, eu tive acesso a todas as escolas pianísticas: a americana, a europeia, a alemã e até um pouco da russa. É muito eclética e outras coisas mais que nem viraram escolas, mas que são um pouco, assim, [silêncio] mais alternativas vamos dizer. Depois, ao longo do tempo, eu fiz uma síntese de tudo isso, inclusive usando meus próprios elementos. Eu uso muito a análise, schenkeriana e outras, e o meu trabalho de corpo, pois fiz muito trabalho corporal. Então, eu procuro fazer uma síntese de tudo na verdade, porque eu entendo que tocar piano é com a alma, com o corpo, com a emoção, com o mental e com os sentidos. Sentidos que a gente vê e aqueles que a gente não vê, com a imaginação, por exemplo, que para mim é um sentido, com a intencionalidade etc. Então, eu procuro fazer uma síntese para que a performance fique unilateral. Eu nasci no Brasil, onde fiquei até uns doze, treze anos, e depois fui para Israel, onde fiquei uns sete anos. Estudei aqui com a Dona Olga Normanha Rizzardo, que veio da escola italiana e também estudou com a família Mignone, como Francisco e Carlos Mignone [silêncio]. Ela também teve conato com Mário de Andrade e conheceu Villa-Lobos etc. etc. Toda a escola brasileira, vamos dizer, não a Chiaffarelli. Chiaffarelli eu tive contato depois, quando eu fui para Nova Iorque. Depois fui para Israel e tive contato com grandes professores, que na verdade vinham da Europa. Meu professor de análise, Haim Alexander, estudou com Bruno Walter só para você ter uma ideia. Ele era um grande improvisador, um grande compositor e um grande professor de análise. Análise schenkeriana em Israel também é muito forte. Eu quase fui para o lado da composição e 
teoria em Israel, mas eu sempre fui pianista e continuei pianista. Tive contato com grandes professores em Israel, tais como Arthur Rubinstein, Claude Frank, Isaac Stern etc. Depois, houve uma época, por exemplo, que eu ia assistir a, praticamente, todos os concertos da Israel Filarmônica, com Zubin Mehta regendo, Bernstein tocando e regendo, muita gente maravilhosa. Depois, eu fui para os Estados Unidos e fiz meu mestrado e doutorado. Lá, tive um encontro com uma professora que era uma grande pensadora da técnica do piano, que tinha uma técnica muito específica, saindo de Tobias Matthay. Também fiz uma síntese com ela. Cada um me dando coisas diferentes. Então, na minha cabeça ficou muito bagunçado. Demorou muito para eu fazer uma síntese, mas eu consegui fazer uma síntese, quer dizer, a gente sempre tem que fazer uma síntese. Essa minha escola é muito eclética, em suma, se eu tivesse que dizer: é muito eclética.

ARM: Fale-me um pouco sobre seu aprendizado da música brasileira ao piano. Como foi seu contato com ela?

SR: Desde criança, Dona Olga sempre dava música brasileira. Eu conheci de perto, por exemplo, Francisco Mignone, com quem tive aulas; Osvaldo Lacerda, conheci; Camargo Guarnieri, conheci; Almeida Prado, grande amigo meu. Tive Guerra Peixe desde criança, Dinorá de Carvalho, Ernesto Nazareth, tudo isso. Comecei aos 5 anos de idade. Quando eu saí do Brasil, com doze anos, eu não deixei meu contato com o Brasil, nem com a língua. Eu continuo falando português, razoavelmente bem, e continuei sempre muito curiosa com a literatura brasileira, a música popular brasileira e a música erudita brasileira. Sempre mantive contato. Eu, por exemplo, fiz meu trabalho de mestrado sobre Alberto Nepomuceno na Juilliard. Aí veio a ideia de fazer um contrato para gravar VillaLobos. Fiz um, e aí, a Naxos pediu para fazer todo o resto. Então, eu acabei sendo sempre relacionada à obra de Villa-Lobos [silêncio]. Tem várias obras que o Almeida Prado compôs para mim, por exemplo, a que fiz a première. Faria muito mais, se eu tivesse os recursos, porque eu queria ter gravado Almeida Prado e ainda gostaria de gravar Almeida Prado. Toquei com Antônio Menezes a peça maravilhosa de Almeida Prado, a Sonata para violoncelo e piano, que é uma das obras máximas dele [silêncio]. Toquei na première com Antônio Menezes, em 2004, e no festival de Campos do Jordão, com ele presente. Gostaria de ter gravado antes de ele morrer, mas não deu certo [silêncio]. Então, essa foi 
uma falta muito grande, porque eu gostaria de ter gravado com ele presente na gravação, mas Antônio e eu tocamos para ele. O meu envolvimento com música brasileira é muito grande e continua sendo muito grande com vários os projetos que eu tenho, incluindo o do Carlos Gomes que agora comecei a pesquisar e a fazer levantamento de obras, a resgatar o piano dele que está aqui em Campinas. Com Villa-Lobos estou com um grande projeto. Enfim, é grande.

ARM: Em sua opinião, quais são os principais compositores brasileiros para piano?

SR: Eu acho que só teremos essa grande perspectiva depois de muitos anos. Eu acho que temos que tocar tudo. Não cabe a nós, performers, fazer essa triagem, uma triagem geral sim, mas não minuciosa. Eu acho que com a perspectiva que a gente tem, essa visão estética maior, eu acho que é importante fazermos tudo o que pudermos dos compositores vivos. Eu, morando fora o Brasil, não tenho tanto acesso a compositores vivos. Vocês que estão no meio universitário e tem compositores da geração de vocês compondo, é imperativo que vocês toquem o círculo de vocês [silêncio]. Entende? Eu toquei muita coisa moderna do meu círculo americano quando eu era estudante. Fiz muita música moderna. Fiz Elliott Carter, conheci o Elliott Carter e toquei para ele. Mas isso são círculos que não estão aqui no Brasil, mas que eu tinha na minha época de estudante. Eu acho que é muito importante ter essa visão e fazer mais. Eu não posso te dizer se aqui no Brasil hoje se faz ou não se faz, mas eu acho que é muito importante. É nosso dever como performers.

ARM: Como foi seu primeiro contato com a obra de Ernesto Nazareth?

SR: Eu não lembro exatamente quando foi a primeira vez que eu toquei Nazareth, mas Nazareth é sempre muito presente no universo de música brasileira para piano. É impossível você falar de música brasileira para piano e não olhar Nazareth, impossível. Eu considero tocar Nazareth muito difícil, [silêncio] mas muito difícil mesmo. Porque primeiro, são peças curtas e peças curtas são muito mais difíceis de tocar do que peças longas. São como os Prelúdios de Chopin. Você tem que, na primeira nota, já construir o universo sonoro até a última. Você não pode se esquentar, tem que entrar no universo 
sonoro desde a primeira nota. O lado, vamos dizer, popular e o lado erudito de Nazareth estão muito entrelaçados e não dá para você dissociar um do outro, mas para você achar a medida certa é como a dificuldade de Mendelssohn, Canções sem palavras. Para mim, na minha cabeça, é muito parecido, porque os dois estão entre estilos, romântico e clássico, no caso de Mendelssohn (compositor completamente mal-entendido), e Nazareth popular, vamos dizer, e clássico. Então, por exemplo, Mendelssohn, se ficar muito romântico está fora, se ficar muito quadradinho está fora. Eu faço essa comparação de propósito, porque é mais fácil a gente olhar isso no Mendelssohn do que no Nazareth, porque no nosso imaginário “Ah tá, 'Odeon’ eu sei como é que é”, todo mundo tem mais ou menos na cabeça “Odeon”. Então, Mendelssohn, Canções sem palavras você dá para criança tocar, eu não entendo como é possível dar para uma criança tocar Canções sem palavras, porque é dificílimo. Mesmo as lentas são dificílimas. Eu nem estou falando do lado técnico, o lado do estilo, porque é um estilo muito específico que ainda não se cristalizou na mente dos performers. Vamos dizer, o estilo de Beethoven se cristalizou na pedagogia; o estilo de Bach erroneamente se cristalizou, muito erroneamente; o estilo de Mozart mais ou menos se cristalizou, também erroneamente; o estilo de Mendelssohn... [silêncio]. Ah! Mais ou menos romântico [silêncio]. As pessoas ainda não pensaram o que vem a ser isso. Então, eu acho que em relação a Nazareth, também não. É dificílimo porque o lado, vamos dizer, rítmico não é preciso, tem que ser justo. É questão de ser isso, mas, não aquilo. Não é preciso, mecanicamente preciso, tem que ser suingado, mas não pode ser demais, então tem que ser sentido da maneira certa. A mão direita tem que ter a graça em cima disso, mas sem mexer nessa graça do ritmo, não é isso que acontece na música popular? O europeu fica louco com isso [pausa], ouvindo. Não sabe como dá para fazer isso. Historicamente, desde quando Milhaud chegou aqui [pausa], tem alguma coisa “Je ne saia pas quoi!". O Milhaud escreveu: tem alguma coisa que eu não sei definir na música tocada aqui no Brasil. Isso na época do Nazareth. Ele não sabia o que era e, olha, ele era um grande músico. Ele não conseguia definir o que isso vinha a ser. Isso é esse swing, essa liberdade que não é liberdade, não é? Não é que não importa, agora vou tocar Nazareth e posso fazer tudo. Não é nada disso. Como na música popular brasileira bem tocada você também não pode fazer tudo, não é tudo que funciona. São estilos que a gente tem que levar muito a sério para conseguir entender. O primeiro concerto em que tive de tocar Nazareth seriamente foi em Nova Iorque. Decidimos, os três pianistas, a 
fazer um concerto só de Nazareth, que nunca tinha sido feito. Uma pianista argentina, Polly Ferman, eu, a única brasileira, e William Bolcom, grande compositor americano (ainda está vivo e adora Nazareth, sempre adorou). Quando ele soube que eu era brasileira e que eu gostava de Nazareth, ficamos amigos. E ele tocou, do ponto de vista dele, Nazareth. Interessante é que cada um tinha o seu jeito de tocar, diferente. Aí eu toquei seis ou sete peças das quais, o "Batuque", por exemplo, "Cuéra", que eu me lembre, e "Gaúcho", que é a última dele, se não me falha a memória. Então, teve bastante repercussão esse concerto. Sempre depois que eu tocava Nazareth em concertos, que foram muitas vezes, as pessoas inevitavelmente vinham me procurar querendo a partitura, que é muito difícil de encontrar lá fora. Internet [pausa], nessa época, ninguém tinha. Ficavam encantados. Então, a atração dessa obra é muito melhor que Scott Joplin. A gente, quando falava nos Estados Unidos, dizia é o Scott Joplin brasileiro, porque era a única maneira deles entenderem mais ou menos. Depois, participei, numa certa época, de um grupo mais ou menos de música popular. Eu fazia os arranjos para saxofone, violoncelo e piano, e algumas das coisas que eu fiz foram arranjos de Nazareth. Para fazer a saxofonista americana entender o que é o suingado brasileiro não havia jeito, não havia jeito! Porque ela fazia como se fosse Scott Joplin e colocava os acentos no lugar errado. Era muito difícil, [pois ela] não tinha no ouvido. É o mesmo problema hoje quando a gente vai numa orquestra. Já comentei isso com várias pessoas, até com Egberto Gismonti. É tudo escrito e, assim, é difícil para eles. O que parece para nós, relativamente claro, para pessoas de fora é muito complicado, por isso eles precisam de uma tradução. É preciso, assim, [silêncio] explicar miudinho por miudinho. Tinham me oferecido para gravar toda a obra do Nazareth, depois de eu já ter gravado toda a obra do Villa, mas não deu, sabe como são essas coisas [silêncio], projeto [silêncio].... Acho que foi o Cacá [Machado] que me pediu para gravar para o livro dele, aí eu gravei. Eu acho que é a única coisa que tem gravada oficialmente. Do que eu fiz só tem gravação ao vivo e algumas coisas que eu fiz no CD desse trio, mas que não foram oficialmente publicadas. Então é isso, ao longo de muitos anos.

ARM: Você comentou sobre a dificuldade de tocar Nazareth. Sobre esse assunto o pesquisador Henrique Cazes, em seu livro Do quintal ao municipal, diz o seguinte: "Um problema à parte é a falta de jeito dos pianistas brasileiros para tocar Nazareth. Se 
ouvimos suas obras executadas pelos chamados pianistas (como a suingadíssima Carolina Cardoso de Menezes), fica faltando um toque de sofisticação. Se as ouvimos tocadas por pianistas clássicos, muitas vezes de sólida reputação no meio erudito, falta o balanço" (CAZES, 1998, p. 36). Comente este trecho.

SR: Exatamente este é o problema e nós temos que ter isso no ouvido. Vamos dizer que para nós, o pianista brasileiro erudito que vai para o exterior e toca Nazareth [falha no áudio]. Eu sou sensível a esse problema, especialmente depois que eu terminei o meu projeto Bach. Eu acho que se eu tocasse Nazareth hoje seria muito diferente do que eu gravei, porque a minha visão mudou muito. Primeiro, eu vi que para eu fazer a tradução que eu fiz no Bach, que foi a tradução do mundo barroco, é muito difícil. Nós temos hábitos, até no corpo, de como tocar. Eu tive que mudar esses hábitos e criar outros, por exemplo, como é que eu, como pianista, faço a mão esquerda e mantenho minha mão direita com rubato. Isso é muito difícil e eu fiz no Bach. Por exemplo, o pianista popular faz isso o tempo todo, pois ele tem o pessoal do ritmo que está junto com ele e a mão esquerda não para, certo? Então é a [mão] direita que tem que se acomodar e tem que suingar. Do mesmo jeito, para eu fazer da maneira que agora estou pensando que faria Nazareth, eu teria que fazer como eu fiz: ouvir muita música barroca com gente do barroco. É introjetar esse som para poder fazer, não de uma maneira calculada, mas sim de maneira sentida. Então, eu concordo com Henrique, mas é uma coisa que a gente ainda está deglutindo, porque houve uma separação muito grande entre o que é erudito e o que é popular. Só para você ter uma ideia, quando eu era pequena, não podia ouvir música popular, era proibido. Dona Olga não deixava [silêncio]. Imagina: tinha uma biblioteca em casa e eu fechava a porta e ficava escondida ouvindo Beatles baixinho. Hoje a gente ouve tudo. Com o YouTube a gente acaba ouvindo tudo, mas precisamos ouvir com discernimento para poder introjetar isso. Essa síntese, no músico erudito, ainda precisa ser feita, eu acho [silêncio]. Não conheço tudo o que está gravado. Eu acho que mais pessoas e mais pessoas estão tentando essa síntese. E essa síntese é muito bem-vinda, porque ela vai também influenciar a maneira como a gente vê a música do passado. Isso é muito benéfico porque, eu acredito, nós não podemos ser performers de acordo com teorias, temos que ser performers de acordo com a música, com a prática dela, com a intenção do compositor, com o que se faz em volta. É isso. 
ARM: Ainda nessa questão, Jairo Severiano em seu livro Uma história da música popular brasileira (SEVERIANO, 2013, p. 40) afirma que "Um tango, como o "Brejeiro", por exemplo, se executado ao piano como o autor escreveu, é uma peça refinada, digna de qualquer sala de concerto. Se, entretanto, é interpretada por um músico popular, passa a ser uma composição chorística, retornando às origens". Você acredita que a interpretação tem esse poder de mudar a designação da música?

SR: Total! Claro que tem, e isso tem a ver com o que o Henrique escreveu. O que isso depende não de fazer esse acento, aquele acento, pegar um pouco de tempo aqui, [silêncio] não é só isso. É o que o performer tem no ouvido, é a vivência do performer. Se a vivência de quem está tocando piano, é uma vivência do mundo popular, de jazz, ele vai tocar diferente. $\mathrm{O}$ ouvinte entende isso, recebe essa mensagem diferente e o pianista pode fazer isso pegando uma valsa de Chopin. Vai também soar com essa cor, com essa cor de pianista que toca música popular. Toda performance é uma tradução, ela passa pela pessoa que está tocando, se integra à pessoa que está tocando. É uma tradução. Não existe uma performance absoluta, ou então, a melhor. Não existe isso. Existem objetos sonoros, esse passou por essa peneira, essa passou por outra peneira, e a peneira pela qual a obra passa, que é a gente, impregna o objeto sonoro. Mesmo que se tenha o compositor presente, por exemplo o Almeida Prado, ele tocava para mim a obra e dizia "isso aqui eu quero assim e isso aqui eu quero assim", e tocava, mas a maneira como eu tocava a obra dele era muito diferente, e ele adorava. Ele gostava da minha diferença. Então, existem pontos que para ele eram importantes e existem pontos que ele gostava da minha peneira, vamos assim dizer. Vamos supor que o Nazareth estivesse vivo hoje, tivesse me ouvido tocar a obra dele, ou outras pessoas, pessoas modernas tocando [silêncio]. Primeiro, ele estaria supercontente que estivessem tocando a obra dele [silêncio]. Chegar a uma performance é o mesmo problema de tocar Bach no piano, Scarlatti no piano. É o mesmo problema. É o que se chama de performance informada, não é? A gente procura estar informado, procuramos ter uma visão consciente do autor, o que é importante para o autor, mas no máximo o que a gente pode ter como performers é uma visão não correta, mas que seja viva. Se ela conseguir chegar ao público, sendo ela muito correta ou não, já é uma coisa boa, e que ela aproxime o mundo do compositor ao do ouvinte. Isso varia 
também. Nas gravações do Keith Jarrett tocando Haendel ou Bach dá para ver que ele é um pianista de jazz, eu noto isso ao ouvi-lo, porque o pianista erudito tem muito mais cor em cada nota. Quer dizer, [silêncio] depende do pianista, mas é possível que o pianista erudito tenha muito mais cor, muito mais controle de cor, controle de dinâmica e justaposições sonoras etc. O Keith Jarrett é excepcional no que ele faz, mas é diferente de um pianista erudito. Não estou falando que é melhor, que é pior, apenas diferente, tem a peneira de um e a de outro.

ARM: Nessas interpretações de músicos populares em que há mudanças no texto musical (acréscimo ou omissão de notas), você acredita que isso seria um arranjo ou uma interpretação do texto?

SR: Do ponto de vista do pianista de jazz, ou popular, ou do chorinho, não é uma reescrita, é a maneira como ele lê a obra. Do ponto de vista dele para o mundo dele, isso é o que eles fazem sempre. E, assim, é ótimo, é lindo. Do ponto de vista de um pianista clássico, a gente toca o que está escrito e as nossas interpretações se dão de acordo com a cor, com o pedal, com o tempo, as relações de frases, as relações de harmonia etc. Dessa forma, o texto musical difere-se de um pianista para outro em nuances que te remetem a esse mundo ou aquele mundo. $\mathrm{O}$ texto musical muda num pianista popular, neste caso é o texto que muda. Eu, por exemplo, adoro, mas aí é outra coisa, o Ney Matogrosso cantando Villa-Lobos, "Melodia sentimental", é maravilhoso. Ele não muda, o que muda é o arranjo, é diferente. São leituras diferentes. Agora, o que você diria, por exemplo, se eu pegasse o texto de um pianista popular e tirasse todas as notas que ele fez, depois, fizesse exatamente igual. Eu ouço, escrevo tudo e toco o que ele fez, como você chamaria isso? Vamos dizer, eu pego uma versão de "Odeon" feita por um pianista popular e toco essa versão. Do meu ponto de vista estou tocando a versão dele, mas do ponto de vista do pianista popular, ele está tocando “Odeon”. Mas é autoral, é dele. Ele está tocando "Odeon". Eu acho que tem muito a ver com a intencionalidade. Acho que nós pianistas clássicos pecamos por fazer tudo certinho, a ideia de certinho... [silêncio] O computador também pode fazer certinho. Hoje em dia, os geradores de som são tão maravilhosos que você pode fazer muito certinho. Então, as pessoas estão perdendo um pouco isso e estão querendo imitar os grandes pianistas virtuoses que hoje fazem uma carreira grande. Eles 
estão indo mais para lado de tocar forte e rápido e estão menos interessados pela obra, que é apenas o veículo para eles mostrarem o que eles podem fazer. E, os jovens estão querendo entrar nessa de também querer pegar uma peça para ser um veículo deles. Vejo nisso um problema.

ARM: Escutando suas interpretações que estão no $\mathrm{CD}$ que acompanha o livro $O$ enigma do homem célebre, do Cacá Machado, percebi que você não muda o texto musical, mas sim a articulação, em que você faz algumas alterações, e a duração das notas, em que algumas você faz mais curta do que está escrito e outras mais longas. Isso ocorre principalmente com na mão esquerda, quando há uma "levada" de um compasso para o outro sempre tem uma variação, o que na música popular é chamado de "molho". Comente um pouco sobre essa questão.

SR: O Wisnik disse que gostou muito e isso foi um grande elogio para mim. O Cacá também gostou muito. Faz tempo que eu não ouço essas gravações. Acontece o seguinte: eu fico contente de você me dizer isso porque eu acho interativo. Por isso que eu falei que depois desse Bach vou mudar muito mais. $\mathrm{Eu}$ estou num diálogo e argumentação filosófica, intelectual e antropológica com o Vincenzo Caporaletti que tem uma teoria chamada Le musiche audiotattili. Ele escreveu um artigo superimportante de 1960, O que é swing? What is swing? A teoria dele diz que esse "molho" acontece na música não escrita e na música escrita isso não acontece. Ele esteve em casa e eu provei para ele que acontece com texto de Debussy, por exemplo. Eu estava tocando Debussy e mostrei para ele. Olha! Isso está escrito assim, mas eu toco assim. Então, é uma interpretação e ele falou "acho que tem uma coisa a ser desenvolvida aí", mas ainda não tivemos tempo de formalizar e formatar esses conceitos, vamos dizer, científicos. De qualquer maneira, é isso que eu digo que é uma interpretação: o quanto é a duração. Se não tem a graça, então eu curto mais, até eu sentir que tem a graça que eu acho que tem que ter. Se for outro pianista vai querer mais graça talvez, ou menos, o ouvido dele não vai precisar disso ali, vai precisar disso em outro lugar. Eu estou querendo encontrar um jeito de que meu discurso musical, que eu construo através do texto de Nazareth, neste caso, tenha as qualidades que eu vejo nesse texto. Por exemplo, o que você está falando, graça, surpresa, se eu hesito um pouco ou um pouco mais, eu crio uma expectativa e uma surpresa; se eu 
faço articulações e as mudo nas repetições, eu também estou criando expectativa. Ah! Está diferente. Então, eu mexo com a expectativa de quem está ouvindo mesmo ela sendo inconsciente. O ouvinte não precisa saber o que eu estou fazendo, ele só precisa estar entregue. Eu não faço de maneira calculada, faço de maneira que preciso sentir. Se eu acho que está meio chato, está meio chato. Eu preciso fazer alguma coisa para que tenha graça. Esse mundo que eu estou tocando tem alguma ligação com o mundo que eu tenho na minha imaginação do que é a música popular, o que é a música popular de Nazareth, como eu imagino o Nazareth tocando no cinema, como eu imagino o pessoal da época ouvindo Nazareth, isso tudo trabalha o meu inconsciente. Tudo que li sobre Nazareth, tudo que li sobre o que é brasilidade, o que é identidade, o que é ser carioca naquela época, [silêncio] entende? Todo esse mundo entra no meu equilíbrio de valores sonoros quando estou construindo o negócio. Não só no nível mental, calculado, mas no nível emocional, emotivo. Eu tenho que ser capaz quando estou tocando. Ah! Que lindinho! Olha que coisinha. Entendeu? Por exemplo, eu também tenho que ser capaz de dizer que essa nota é estrutural, como você sabe do Schenker, ela se liga aquela lá no fim, eu também tenho que ser capaz de fazer isso em Nazareth, porque eu também faço isso em Nazareth. Eu construo um texto musical com vários sistemas, porque se você construir só pelo emocional, ele ficará pequeno. Por que eu fiz isso aqui assim? Ah! Porque eu senti isso. Isso não é suficiente. Ele não pode ir contra outra coisa que está acontecendo. Não estamos falando de uma peça específica, mas da maneira como eu penso, entendeu? É bem complicado isso. Eu acho que o que é importante é a minha intenção de criar esse universo. Nós procuramos um caminho para performance, e nesse caminho há mais perguntas do que respostas. Você vai construindo, vai costurando uma coisa.

ARM: As músicas de Nazareth são tangos, maxixes, etc. Você pensa na origem dessas danças, tocando como se fosse para dançar, mesmo sabendo que Nazareth compôs para que fossem apenas ouvidas?

SR: Acho que tem a base. Maxixe, por exemplo, Rudepoema começa com maxixe, de Villa-Lobos. Ele dá uma cor para o negócio. Ele dá um gostinho. Eu não penso que é para dançar, talvez eu devesse, mas eu não penso. Eu penso que é uma obra artística baseada em dança. O fato de ele chamar polca, schottisch, valsa, etc. Valsa não, acho que valsa é 
diferente. Acho que seria mais uma coisa marqueteira talvez. Eu não sei se na época eles dançavam com a música do Nazareth. Pode até ser que dançassem, mas a música não era feita para dançar, essa não era a intenção. A intenção da obra não era dançar, como também não era intenção da Allemande de Bach, mas ela é baseada na dança, os apoios, os tempos, eles vêm desse mundo. É bem importante ter essa noção [silêncio]. Agora estou pensando com você, eu nunca tentei pesquisar e ver essas danças na origem, como é que eram dançadas, para ver se tem alguma coisa. Por exemplo, o schottisch, eu não sei como se dança o schottisch, mas quando tem, por exemplo, uma coisinha de baião, eu sei como se dança o baião, está na minha cabeça e, então, é só dar uma cor. Eu acabei de achar um pedaço de baião nas Bachianas $n^{\circ} 3$ de Villa-Lobos, demorou um pouco, mas eu entendi que era baião. Isso aparece como uma cor, como se você fosse um pintor e desse uma pincelada a mais. Tem essa cor que te remete a isso, mas não é para você sair dançando, é apenas uma alusão a esse mundo simbólico. Eu acho isso importante. Então, não é primeiro grau de importância, é segundo, terceiro, quarto grau.

ARM: Ao lermos a bibliografia acerca da obra de Ernesto Nazareth, encontramos afirmações como do pesquisador Mozart Araújo (apud SALLES, 1994, p. 88): "Nazareth fez de seu piano uma espécie de síntese da música dos chorões”; e do Henrique Cazes (1998, p. 36): "Nazareth traduziu a música dos chorões para o piano". Comente essas afirmações.

SR: Concordo totalmente. Eu tive uma experiência quando eu ainda morava em Nova Iorque e tive de tocar uma vez. Eu tinha uma amiga que tocava música popular num bar. $\mathrm{Na}$ época eu estava muito longe disso. Eu vinha da época em que era proibido ouvir música popular. Era estudante e não tinha no meu ouvido, mas tive que ajudar, tive que ir lá e tive que improvisar música popular. Tinham outras pessoas tocando comigo. Era música popular brasileira e eu tive que improvisar no piano. Como era difícil fazer essa tradução para o piano, pois é o que você põe e é o que você não põe. Nessa tradução, por exemplo, o Villa-Lobos também fez com relação ao samba, "Vamos atrás da Serra Calunga" é um samba. Como é que ele põe essa mão esquerda para dar ideia das camadas de ritmos que tem numa música popular, que é supercomplicado? São as camadas, são os timbres diferentes, é muito rico. O Nazareth conseguiu fazer isso muito bem, e isso é 
genial. Quando você olha o texto é simples, não tem muita nota, mas ele é exatamente isso. Ele é uma síntese literal do mundo sonoro do choro. Então, quando você ouve choro e ouve Nazareth [silêncio]. Nossa, rapaz! Como é que ele conseguiu fazer isso?! E é genial, porque é com poucas notas. Agora, eu fui tentar fazer o mesmo sozinha, mas eu não sou genial. Eu não consegui fazer isso. Só depois fui entender a genialidade dele, e de outros também, que fazem isso através desse exercício. Outra coisa, por exemplo, que me vem à mente dizer: Liszt sintetizava as Sinfonias de Beethoven para o piano, aí você vê a genialidade dele. É genial o que ele põe e o que ele não põe, mas aí já é, de certa maneira, mais fácil porque o texto está lá, mas é uma síntese. Então, eu concordo plenamente, é genial.

ARM: Ainda nesse sentido, Robervaldo Linhares Rosa (2014) afirma que a 'rua' foi matéria-prima para muitas das músicas de Nazareth, e em sua forma de tocar, pode-se perceber que era evocada ao piano a sonoridade dos instrumentos chorões, como o violão, o cavaquinho e a flauta, numa verdadeira transposição do ambiente público, seresteiro e de choros, para o espaço privado e confortável, por exemplo, da sala de espera do Cinema Odeon, (ROSA, 2014, p. 90-91.) Você concorda que é perceptível, ao tocar, essa alusão que o referido autor nos informa?

SR: Totalmente evocada. Imagina, a gente ouve a flautinha ali, ouve o violão aqui, nos acordes do meio, pa-pa-pá [Sônia canta o ritmo: colcheia, colcheia pontuada e semicolcheia], ouve baixos, então, é totalmente evocada. Muito bem feito, genialmente evocada.

ARM: Quando ouço suas interpretações, sou induzido a escutar esses instrumentos, por exemplo: em alguns trechos eu percebo nitidamente um violão de sete cordas. Para mim, é nítida a transposição desse universo em sua interpretação. Você pensou realmente nisso ou foi apenas meu ouvido que induziu essas conclusões?

SR: Acho que foi no sentido de uma construção, como eu falei para você, a maneira como eu construo uma performance. Eu acho que eu tive essa noção sim. O caminho para se construir camadas sonoras no piano é muito importante. Eu não gosto muito quando se 
toca as coisas, assim numa coisa só, em geral como se faz. Eu gosto de construir camadas sonoras diferentes, acho que fica muito mais interessante. Então, estou sempre destrinchando. Se for uma mão esquerda, seja onde for, Mozart, baixo de Alberti, penso em vozes, contraponto. Por exemplo, os baixos da mão esquerda de Nazareth são dificílimos, porque tem uma nota do baixo e tem três vozes ali que mudam. Justamente por isso, é que é tão difícil tocar Nazareth bem [silêncio]. Não é apenas um acorde e sim três vozes que estão no meio desse acorde. O acorde do meio tem três vozes. Qual voz você quer? Para onde elas vão? Até onde elas vão? Qual o clímax delas? Você entende? [silêncio] Nessas camadas sonoras, eu penso muito nisso, muito! Não é fácil, não sai fácil, tem que trabalhar para sair. Ainda mais com aqueles pulos da esquerda, é muito difícil. É muito difícil tocar bem Nazareth. É uma das coisas mais difíceis que eu já fiz, para te dizer a verdade.

ARM: Você já disse que sente a música para escolher os acentos entres outros quesitos ditos anteriormente. Mas especificamente, você pensa em acentos e articulações que evocam o violão, a flauta, ou simplesmente as camadas e as suas funções (baixo, melodia, etc.)?

SR: Se você pensa em camadas, forçosamente você tem que pensar em quem estaria tocando isso. Forçosamente! Eu não penso em piano, aliás, o piano é capaz de orquestrar qualquer coisa. Então, estou sempre pensando: que instrumento faria isso? Você entende? Eu não penso no piano como só o piano em si, penso em orquestração, forçosamente. Quem estaria tocando esse baixo? Quem estaria tocando esse do meio? E se estivesse tocando esse do meio, como sairia? Mesma coisa com o começo do Choros $n^{\circ} 5$ do VillaLobos: é um violão. Penso muito nisso, sim. Penso em instrumentação.

ARM: Continuamos conversando, até nos despedirmos. 


\section{Considerações finais}

A presente entrevista contribuiu imensamente para minha pesquisa acadêmica de mestrado (concluída em 26 de junho de 2017), que tem por propósito investigar a diversidade de interpretações da obra de Ernesto Nazareth, cuja performance tem sido realizada tanto por pianistas eruditos como por rodas de choro. Desta forma, tive a oportunidade de ter a contribuição da pianista Sônia Rubinsky, onde deixa claro que ao construir uma performance, ela pensa em camadas sonoras, o que forçosamente leva à pensar em instrumentação, neste caso a instrumentação do choro, uma espécie de síntese do grupo de choro (violão, cavaquinho e flauta) ao piano. Com certeza, essa entrevista foi uma aula inesquecível.

\section{Referências}

CAZES, Henrique. O Choro: do quintal ao municipal. São Paulo: Ed. 34, 1998.

MACHADO, Cacá. O enigma do homem célebre: ambição e vocação de Ernesto Nazareth. São Paulo: Instituto Moreira Salles, 2007.

ROSA, Robervaldo Linhares. Como é bom poder tocar um instrumento: pianeiros na cena urbana brasileira. Goiânia: Cânone Editorial, 2014.

SALLES, Vicente. Rapsódia Brasileira. Fortaleza: Universidade Estadual do Ceará, 1994.

SEVERIANO, Jairo. Uma história da música popular brasileira. São Paulo: Ed. 34, 2013 (3 Edição). 


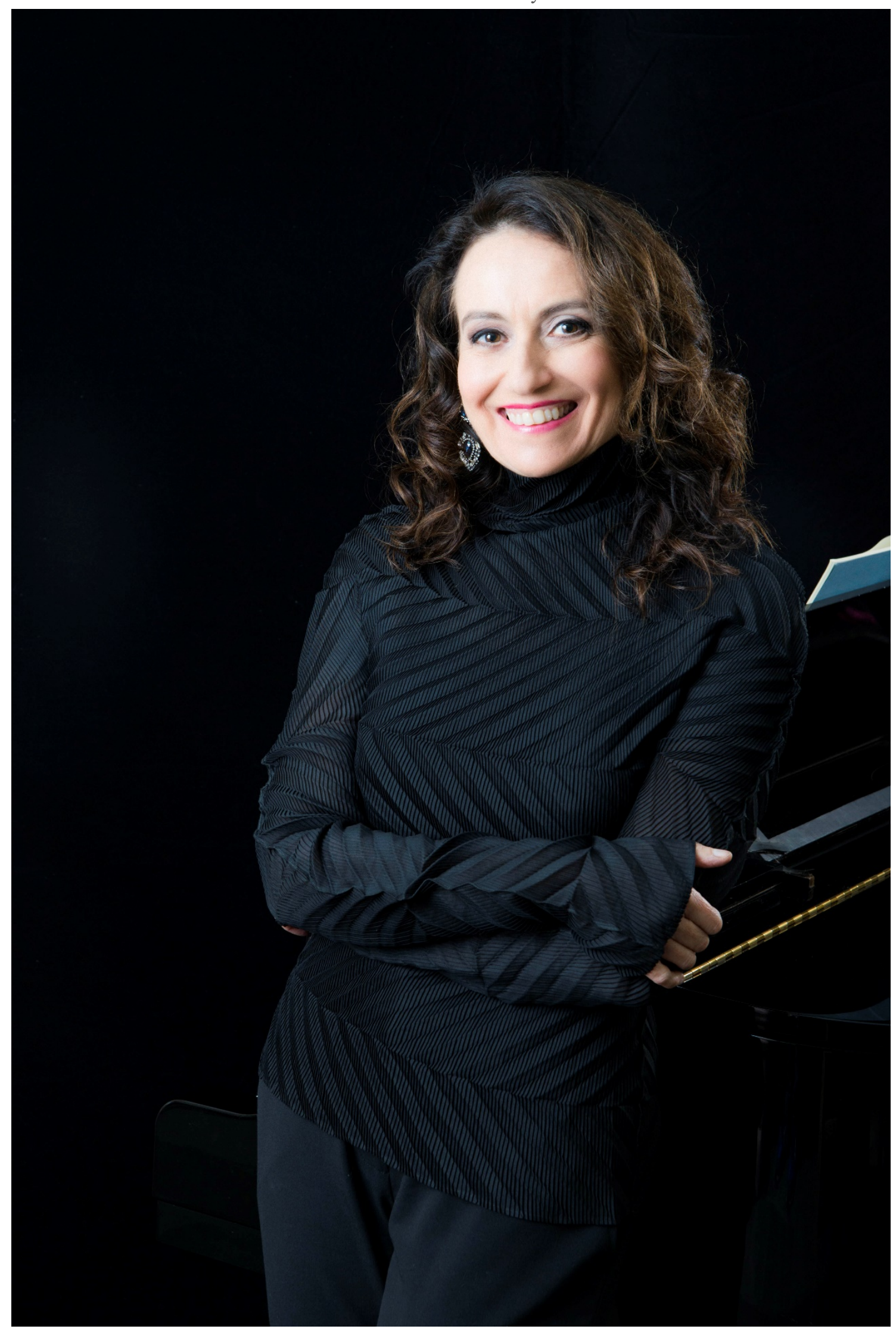

